\title{
Trajetórias paralelas: Os Jogos Pan-americanos e a RBME
}

Minha trajetória na RBME iniciou-se em 2001, quando fui convidada a participar como assistente editorial deste periódico. Nossas aspirações eram muitas: aumentar o número de artigos submetidos e conseqüentemente publicados, melhorar a qualidade dos trabalhos científicos, buscar indexações, melhorar o processo editorial, enfim, aumentar a visibilidade da RBME.

É interessante fazer um paralelo entre o caminho trilhado pela RBME e o esporte brasileiro neste século que está apenas começando. Se em 2001 iniciávamos a renovação da RBME, também em 2001 o Brasil se candidatava para sediar os Jogos Pan-americanos de 2007. Em 2002 o Rio venceu a batalha e conseguiu o direito de sediar os Jogos. Também em 2002 foi constituído o novo corpo editorial da RBME, tendo o Prof. Antonio Claudio Lucas da Nóbrega como editor-chefe. Desde então, a RBME e o Rio de Janeiro (porque não dizer o Brasil?), passaram por períodos de euforia com cada um dos sucessos alcançados no dia-a-dia. Mas também passamos por momentos de ansiedade e medo: escassez de financiamento; dificuldades nos cumprimentos de prazos; insatisfação de autores.

Em 2007 chegamos a um novo patamar: vencemos! O Brasil mostrou-se capaz de sediar Jogos incríveis. A população participou e realmente "viveu a energia" dos Jogos. De nossa parte, nestes cinco anos, a RBME cresceu e se consolidou como um dos principais periódicos das Américas no campo das ciências dos esportes. Nossos voluntários - e aqui vai um agradecimento a cada um dos membros do corpo editorial - vestiram a camisa e cada vez mais temos revisores empenhando sua função com qualidade, dedicação e em prazos adequados.

Há cinco anos seria quase utópico pensar em uma edição da RBME contendo 14 artigos inéditos, todos focando a prática esportiva, e até com autores internacionais. Também há cinco anos muitos duvidavam que o Brasil fosse capaz de sediar os Jogos Rio 2007 com a qualidade com que foram apresentados. Hoje, apresentamos este número da RBME, especial dos XV Jogos Panamericanos e III Jogos ParaPan-americanos, com a certeza de que fomos bem sucedidos até aqui, mas que ainda existem muitos recordes a serem alcançados e batidos. Seguindo o paralelo entre a carreira esportiva da cidade do Rio de Janeiro e a trajetória da RBME: da mesma forma que os XV Jogos Pan-americanos se encerraram com a proposta de candidatura da cidade à sede das Olimpíadas de 2016, a RBME encerra mais esta etapa, radiante por ter sido classificada como periódico internacional pela CAPES (Qualis), porém sabendo que nosso principal desafio continua à frente: a busca pela indexação no Medline!

Não poderia encerrar este editorial sem fazer alguns agradecimentos essenciais. O primeiro à atual diretoria da SBME, principalmente ao seu Presidente, Prof. Arnaldo Hernandez, que confiou a mim a nobre tarefa de seguir como editora-chefe da RBME. O agradecimento seguinte, mas não menos importante, vai para o Prof. Antonio Claudio Nóbrega, com quem iniciei contato ainda na graduação, como aluna de iniciação científica há 10 anos. Muito aprendi com este profissional exemplar, não só na RBME, mas em nossas diversas parcerias, e conto com a experiência de nosso editor-sênior, nesta nova etapa da RBME. Finalmente, agradeço a todos aqueles que participaram do crescimento da RBME: empresas parceiras, autores, revisores, membros do corpo editorial e leitores.

Seguimos em frente, com foco no Medline!

Renata R.T. de Castro Editora-Chefe 